\title{
Higher Education in Kenya: The Rising Tension between Quantity and Quality in the Post-Massification Period
}

\author{
Nickanor Amwata Owuor \\ Correspondence: Nickanor Amwata Owuor, Department of Business and Management Science, University of \\ Kurdistan-Hawler, 30 Metre Avenue, Erbil, Iraq. Tel: 964-77-0652-3954. E-mail: n.amwata@ukh.ac
}

Received: September 26, 2012 Accepted: October 22, 2012 Online Published: November 28, 2012

doi:10.5539/hes.v2n4p126

URL: http://dx.doi.org/10.5539/hes.v2n4p126

\begin{abstract}
This paper was designed to be an empirical study, looking at the disparity between quantity and quality in higher education in Kenya. To enable a systematic look at quality and quantity within context, a combination of approaches: case study, delphi technique, observation and interviews were adopted for the purpose of this study. The research validated the common perception of massification and corresponding poor quality in the higher education sector in Kenya; reflected by the poor measures in all the aspects of HE quality: Breadth of teaching, learning and assessment activities, students' achievement, the curriculum, learning resources, student support and guidance, and academic management at subject/department level. The results present serious concerns which require urgent attention and action. Several action points have been suggested that can prove useful in bringing about the necessary reforms in order to revitalise HE for the sake of enabling the achievement of Vision 2030 (the country's grand development programme).
\end{abstract}

Keywords: quality, massification, higher education, Kenya, university

\section{Introduction}

\subsection{Higher Education in Kenya-The Problem}

Jowi (2003) describes the national education sector in Kenya as "in crisis". In fact he berates the Ministry of Education for remaining in perpetual denial about this crisis by reaffirming its false confidence in the current system.

The whole problem can perhaps be attributed to a phenomenon called "massification". The term 'mass higher education' was traditionally employed to describe the growth of enrolment beyond the level of academic reproduction and training for a small number of occupations requiring this education for demanding professions and privileged social positions. Scott (1995) used the term massification to describe the development of mass higher education during the latter part of the twentieth century. Evidently the steady increase in university enrollment without corresponding increase in budgetary allocation and investment in facilities has arguably led to a quantity-quality mismatch. To make matters worse, the government has gone ahead and introduced in the 2011/2012 academic year, double intake in all the universities, further compounding the problem. This study therefore helps to identify the nature and magnitude of this problem.

\subsection{Massification of HE in Kenya}

There has been continuous and rising demand for higher education in Kenya, and the university system has been forced to stretch to the brim to cash in on this increasing demand. Among other ways, public universities responded to this development by mounting privately sponsored programmes - commonly referred to as parallel degree programmes - whereby, apart from the regular students sponsored by the government, universities are also admitting students who are self-sponsored. These students take their lectures separately in the evening and during weekends or in some cases together with their regular counterparts. The public universities have also resorted to taking over a number of what used to be middle level colleges; a matter whose purpose and supposed benefits have evoked mixed reactions. The 1980s and 90s witnessed the emergence of private higher education institutions and universities in Kenya. Most of these were started by faith based organisations and community organisations; and of late even by individuals and professional associations like professional bodies of accountants and managers. The growth of the private university sector in Kenya has been fuelled by several factors, including: the limited opportunities available in public universities; the constant closures of state-funded 
universities because of strikes by staff or students; the need to complement government-managed higher institutions of learning; and the determination by some religious organisations to open higher learning institutions largely for their followers (Ngome, 2003).

The term massification has been used in other contexts to refer to the increase in number of institutions. But in the context of this study, it is defined in terms of not just increased number of institutions but rather increased enrollments in HEIs in Kenya.

\subsection{Enrollment Statistics}

There are five publicly funded universities in Kenya, in addition there are twenty four private universities and fourteen University Constituent Colleges (University Constituent Colleges have each been established since 2007 by a Legal Order and placed under a public university. University Constituent Colleges are envisaged to grow to become fully fledged universities in future).

Table 1. Enrolment statistics*

\begin{tabular}{|c|c|c|c|c|c|c|c|c|c|c|c|c|}
\hline & \multicolumn{2}{|c|}{ 2004/05 } & \multicolumn{2}{|c|}{ 2005/06 } & \multicolumn{2}{|c|}{ 2006/07 } & \multicolumn{2}{|c|}{ 2007/08 } & \multicolumn{2}{|l|}{ 2008/09 } & \multicolumn{2}{|l|}{ 2009/10 } \\
\hline & M* & $\mathbf{F}$ & $\mathbf{M}$ & $\mathbf{F}$ & $\mathbf{M}$ & $\mathbf{F}$ & $\mathbf{M}$ & $\mathbf{F}$ & $\mathbf{M}$ & $\mathbf{F}$ & $\mathbf{M}$ & $\mathbf{F}$ \\
\hline NAIROBI & 21268 & 11706 & 21940 & 11765 & 22513 & 12426 & 23513 & 12826 & 29885 & 16115 & 27159 & 15201 \\
\hline KENYATTA & 11252 & 4803 & 10896 & 4787 & 8845 & 7891 & 10172 & 8290 & 14041 & 10587 & 17240 & 7388 \\
\hline MOI & 6796 & 5214 & 6831 & 5314 & 8604 & 6,059 & 8674 & 5768 & 12274 & 8025 & 13600 & 6699 \\
\hline EGERTON & 6350 & 2247 & 6262 & 2236 & 8163 & 4006 & 8262 & 4205 & 6477 & 3239 & 6510 & 3201 \\
\hline JKUAT & 4315 & 1959 & 4207 & 1673 & 4460 & 1,845 & 5450 & 2512 & 9170 & 4317 & 9036 & 4451 \\
\hline MASENO & 3413 & 2168 & 2826 & 1878 & 2778 & 1937 & 3487 & 2199 & 3603 & 2257 & 3331 & 2176 \\
\hline MMUST & & & 775 & 287 & 1154 & 656 & 1946 & 803 & 3869 & 1934 & 4119 & 2584 \\
\hline \multicolumn{13}{|l|}{ CONSTITUENT } \\
\hline COLLEGES & - & - & - & - & - & - & - & - & - & - & 16437 & 10761 \\
\hline \multicolumn{13}{|l|}{ PRIVATE } \\
\hline ACCREDITED & 3796 & 4546 & 4215 & 4624 & 8975 & 6973 & 9688 & 10469 & 10172 & 10992 & 19132 & 13583 \\
\hline \multicolumn{13}{|l|}{ PRIVATE } \\
\hline UNACCREDITED & 801 & 907 & 853 & 947 & 2853 & 2091 & 583 & 392 & 618 & 416 & 644 & 240 \\
\hline TOTAL & 57991 & 33550 & 58805 & 33511 & 68345 & 43884 & 71775 & 47464 & 90109 & 57882 & 117208 & 66284 \\
\hline
\end{tabular}

Source: Commission for Higher Education, Kenya (www.che.or.ke)

*provisional data from institutions submitted to Commission for Higher Education

** $\mathrm{M}=$ Male, $\mathrm{F}=$ Female

Table 1 presents the statistics of enrollment in the universities in Kenya according to Commission for Higher Education, Kenya. It is evident that the enrollment has doubled over a period of five years. As of 2009 the corresponding number of academic staff in the public universities can be seen in Table 2. Of course the staff-student ratio is therefore a serious thing to worry about here.

Table 2. University Academic Staff by Qualification 2009

\begin{tabular}{|c|c|c|c|c|c|c|c|c|c|}
\hline $\begin{array}{l}\text { University } \\
\text { Name }\end{array}$ & $\begin{array}{l}\text { Doctorate } \\
\text { male }\end{array}$ & $\begin{array}{l}\text { Doctorate } \\
\text { Female }\end{array}$ & $\begin{array}{l}\text { Doctorate } \\
\text { Total }\end{array}$ & $\begin{array}{l}\text { Doctorate } \\
\%\end{array}$ & $\begin{array}{l}\text { Masters \& } \\
\text { Below Male }\end{array}$ & $\begin{array}{l}\text { Masters \& } \\
\text { Below } \\
\text { Female } \\
\end{array}$ & $\begin{array}{l}\text { Masters \& } \\
\text { Below } \\
\text { Total } \\
\end{array}$ & $\begin{array}{c}\text { Masters } \\
\%\end{array}$ & Total \\
\hline NAIROBI & 540 & 133 & 673 & 46 & 560 & 238 & 798 & 54 & 1471 \\
\hline MOI & 249 & 41 & 290 & 37 & 345 & 143 & 488 & 63 & 778 \\
\hline KENYATTA & 398 & 177 & 575 & 70 & 158 & 86 & 244 & 30 & 819 \\
\hline EGERTON & 108 & 34 & 142 & 39 & 172 & 49 & 221 & 61 & 363 \\
\hline JKUAT & 165 & 45 & 210 & 38 & 272 & 71 & 343 & 62 & 553 \\
\hline MASENO & 159 & 63 & 222 & 32 & 313 & 164 & 477 & 68 & 699 \\
\hline MMUST & 68 & 6 & 74 & 25 & 168 & 55 & 223 & 75 & 297 \\
\hline Total & 1687 & 499 & 2186 & 287.0024 & 1988 & 806 & 2794 & 413.4802 & 4980 \\
\hline
\end{tabular}

Source: Commission for Higher Education 
Even though the data as presented above may not be complete, in the sense that there is no indication of what is the FTE(Full Time Equivalent) for staff or even student, just a cursory look gives a picture of a faculty to student ratio that points towards below standard.

\subsection{Higher Education Funding Issues in Kenya}

Right after the achievement of independence in 1963, the new government in Kenya recognised the role of education in promoting economic and social development as spelt out through Sessional Paper No. 10 of 1965 on African Socialism and its Application to Planning in Kenya (Sifuna, 1998). This necessitated the rapid expansion of the education system to provide qualified persons replace the departing colonial administrators, and to undertake some reforms to reflect the aspirations of the country as an independent state (Court \& Ghai, 1974). Everything seemed to work well in the sixties, seventies and early eighties, but since the mid 1980s government funding to public universities declined considerably in real terms. In fact public universities in Kenya continue to rely heavily on the government capitation, which is pegged at Kshs. 120,000 (approximately US\$1,445) per student per academic year.

However, the government contribution has increasingly diminished, leading to serious financial problems. In relative terms, the proportionate share of the Ministry of Education budget devoted to public universities declined steadily over the years from 20 percent in 1991 to 12 percent in 2000/2001 (World Bank, 2004). It has however since improved a little bit with the allocation for Ministry of Higher Education going up by Kshs2.6 billion to Kshs 26 billion in 2010/201, a record so far (Mulunda \& Ondari, 2010). But even though the aggregate figure allocated to universities has gone up, the capitation is still the same as was fixed in the early 1990s. This means the institutions are expected to take in more but have less allocation per head. The shrinking allocation to public universities has led to insufficient facilities and stalled infrastructural projects in many universities in the country. Several factors can be attributed to have led to this sorry state of affairs. According to Wangenge-Ouma (2007), the causes for this deterioration have been many including changing donor priorities, changing government rules and regulations to cope with national economic turbulence, international economic trends, legislation and political trends in the country.

The private institutions are not any better since they depend on the tuition fees they generate from their students for their revenue; and such heavy dependence on tuition coupled with lack of alternative income sources have made these institutions expensive and thus unaffordable for most Kenyans, in effect, limiting their services to those of high socio economic status. As "profit-making institutions", fees are charged strictly in accordance with market forces on the basis of full cost recovery (Ngome, 2003).

\subsection{Research Questions}

The research question specifically addressed by this study is: Given the recent massive increase in student numbers in HEIs in Kenya, is quality of higher education compromised, and how big is the challenge?

\section{Literature Review}

\subsection{Quality in Higher Education}

\subsubsection{Meaning of Quality}

A review of various management literature by Tam (2001) has revealed that the term quality has different meanings to different scholars and has been variously defined as excellence (Peters \& Waterman, 1982), value (Feigenbaum, 1951), fitness for use (Juran \& Gryna, 1988), conformance to specifications (Gilmore, 1974), conformance to requirement (Crosby, 1979), defect avoidance (Crosby, 1979), meeting and/or exceeding customers' expectations (Parasuraman et al., 1985), etc. Overall, the meaning of the term quality remains hugely debated in various fields, be it business or education and so on.

More specifically in the realm of education, Cheng and Tam (1997) defined education quality as "the character of the elements of input, process, and output of the education system that provides services that completely satisfy both internal and external stakeholders by meeting their implicit and explicit expectation".

To a large extent, this definition includes the important characteristics of quality espoused in management literature. It stems from it that education quality is a multi-dimensional concept and cannot be easily assessed by only one indicator.

However, just like in the debate about quality overall, even within the sphere of higher education, indeed what counts as quality continues to be contested (Barnett, 1994; Schuller, 1991). Perhaps no one puts it better than Harvey and Green (1993). According to them, "quality is a term relative to the user and the circumstances involved. So indeed it may mean different things to different people, and the same person may adopt different 
conceptualisations at different moments" p.10.

There are a variety of stakeholders and actors in higher education, including students, employers, teaching and non teaching staff, government and its funding agencies, accreditors, validators, auditors, and assessors (including professional bodies) (Burrows \& Harvey, 1992). Each of these stakeholder groups have a different view on quality, influenced by their interest in higher education. Barnett (1994) described the quality debate by different groups of actors in higher education as a 'power struggle'. Each of their views represents a valid expectation of higher education and about its quality. Therefore the measurements thus required and the standards to be applied will surely be different for each of these notions of quality (Tam, 2001).

In the teaching and learning area, a new vocabulary representing different monitoring systems has thus been created and are also widely used. These include: Quality control, Quality assurance, Quality audit, Quality assessment, Indicator systems.

The development of Perfomance Indicators (PIs) in higher education can be traced back to manufacturing industry and relates to the way in which inputs are transformed into outputs (Johnes \& Taylor, 1990). Put in the university context, the theory examines the relationship between the outputs that universities aim to achieve and the inputs they need to produce those outputs.

According to Johnes and Taylor (1990), "if universities are to be evaluated, it is therefore necessary to acquire information about:

1. the outputs which universities aim to produce;

2. the inputs which universities need to produce these outputs;

3. quantitative measurements of each university's inputs and outputs;

4. the technical relationship between inputs and outputs".

Such emphasis on the link between inputs and outputs emanates from a political motive of comparing institutions to estimate what each university could have produced with the inputs available to it.

\subsubsection{The Need for Quality in HE}

Demand for accountability and increasing interest in institutional improvement have led to an increased focus on various aspects of quality in HE (Patrick \& Stanley, 1998). More recently, as pointed out by Saarinen (2010), quality has turned from a debatable and controversial concept into an everyday issue in higher education. But as a result of the diversity of views about quality and higher education, a variety of systems and approaches have been developed for monitoring quality of different kinds and at different levels, displaying varied emphases and priorities and various models put forward for assessing quality (Cheng \& Tam, 1997; Tam, 2001).

During the last several years dramatic changes have emerged in the way governments interact with higher education institutions. In fact governments are no longer as receptive to the traditional self-regulatory processes that have dominated university development for ages. Alexander (2000) goes on to observe that "a new economic motivation is driving states to redefine relationships by pressuring institutions to become more accountable, more efficient, and more productive in the use of publicly generated resources. Earlier attempts by states to measure institutional efficiency and performance have generally been met with passive resistance or benign neglect in academic circles. Although this trend still prevails, an increasing number of educational leaders are now exhibiting an awareness that the status quo is no longer a viable option for higher education". This is so true as properly pointed out by Barnett (1992), "that our higher education systems have entered "the age of disenchantment" and "society is not prepared to accept that higher education is self-justifying and wishes to expose the activities of the secret garden. With greater expectations being placed on it, higher education is being obliged to examine itself or be examined by others" (p. 16). Therefore Barnett's observation captures and truly reflects the increasing societal requirement that colleges and universities must become more responsive to national economic needs and new governmental demands for increased performance. Therefore the demand for quality is a leading societal concern.

For governments, it's a delicate balance between adopting public policies advancing the democratic concepts of massification and universality of higher education and rejecting the more traditionally restrictive practices grounded in meritocracy and exclusion and at the same time insisting on quality assurance. Writing in The Economist, David (1997), characterizes massificationas "the biggest single change in higher education over the past two decades".

This current thrust of the "accountability movement" together with national pressure to expand higher education services has been the creation and refinement of state evaluation systems devised to monitor and assess 
institutional effectiveness and productivity (Cowen, 1996).

\section{Study Design}

This was an empirical research project. Both qualitative and quantitative data was collected from literature and a combination of primary sources; mainly from academics, administrators and students; and from observation. To obtain an initial idea about the situation, one HE institution was purposely selected for case study analysis; observations, and interviews with students, and staff were conducted across the institution. As per prior agreement with the administration of the institution, the identity of the case institution has not been revealed. To cross check the data gathered from the case study, the delphi technique was administered, primarily on academics from various universities in the country, to validate and explore the challenges, attitudes and needs in the HE sector in Kenya. The Delphi technique mainly developed by Dalkey and Hemler (1963) at the Rand Corporation in the 1950s is a widely used and accepted method for achieving convergence of opinion concerning real world knowledge solicited from experts or subjects. Therefore the Delphi technique is well suited as a means and method for consensus-building by using a series of questionnaires to collect data from the panel of selected subjects (Dalkey \& Hemler, 1963). Delphi, in contrast to other data gathering and analysis techniques, employs multiple iterations designed to develop a consensus of opinion concerning a specific topic. Other notable characteristics inherent with using Delphi technique are the ability to provide anonymity to respondents, a controlled feedback process, and the suitability of a variety of statistical analysis techniques to interpret the data (Dalkey \& Hemler, 1963).

For the Delphi technique, a total of thirty six participants, representing academics, were purposively recruited from various universities in Kenya.

An initial open ended question was formulated; "What do you think of quality in the HE system in Kenya?"All responses were collated into a list according to frequency of responses and categorised into broad themes before sending back to the respondents for comments and further opinion. This continued in iterative rounds until the respondents agree or disagree with each issue. Theoretically, the Delphi process can be continuously iterated until consensus is determined to have been achieved. However, Cyphert and Gant (1971), Brooks (1979), and Custer, Scarcella, and Stewart (1979) point out that three iterations are often sufficient to collect the needed information and to reach a consensus in most cases.

Correspondence with the subjects was mainly electronically. An online Survey Monkey tool had been developed for that purpose (see http://www.surveymonkey.com/s/QV32KYV). A link to the survey page was sent via email to all the respondents. To accelerate and enhance the rate of response, telephone calls were made and reminder emails sent.

For the analysis, Statistical Package for Social Sciences (SPSS) was used.

The study was conducted over the period between July and September, 2010.

\section{Results}

\subsection{Case Study Analysis}

For the institution that was adopted for case study analysis, a combination of approaches, including; observation, interviews with students and staff and analysis of documents was adopted. One administrator, five students and three lecturers were conveniently selected for interview.

There was clearly shortage of staff and facilities at the institution. The problem of inadequate facilities led to lecturers having to teach all the year round without a break. Also apart from the regular teaching, there were parallel progammes running concurrently during the day as well as in the evenings and weekends that required teaching staff. As a result, lecturers had huge teaching loads to meet the gap and make money in the process. One lecturer put it thus:

"I teach Monday to Saturday. All the hours I teach can add up to 36 a week" (Personal Interview, July 2010)

A peek into one of the lecture rooms revealed up to 100 students crammed together, with others even standing as the lecture was going on. This is what one of the administrators had to say:

"This institution has just recently been upgraded from a simple campus to a constituent college. There was only one programme admitting just about 80 students a year, but now we have added 5 new programmes, increasing the number of new students admitted this year to about 360. A large chunk of the government's allocation for establishing new facilities has not reached us yet. Well, there are a few new projects there; you can see the work is in progress. But the pace is slow due to financial regulatory bottlenecks and some bit of bureaucracy. So it might take some few years before these new facilities are ready for use. In the meantime we are trying to cope as 
much as possible. We have converted some of the staff residential houses into offices to accommodate the new departments. We have also hired some venues in town. Some of our programmes are housed there."(Personal Interview, July 2010)

An interview with some of the students revealed that these large numbers definitely reflected on the delivery and student support. Some of the students had this to say:

"There is no doubt that we are here just to acquire degrees. Otherwise talk of proper teaching, a big NO. Lecturers just make technical appearances and after that we hardly see them, even if you have questions you would want to consult them on." (Personal Interview, July 2010)

"We just study on our own. I wish that instead of wasting money putting up new buildings, the government would better just build and stock the library. It's all the same." (Personal Interview, July 2010)

However when the students' assertions were put to one of the lecturers, he countered them thus:

"It's not true that we don't like to stay around. We don't have offices, so even if we stayed, where will we work from? The corridors?" (Personal Interview, July 2010)

There was no doubt that there were no more tutorials; which have been largely replaced by lectures.

I also noticed students move with their chairs between lecture rooms and when I enquired I was told they may have been going for large lectures and there was shortage of chairs.

Another issue that was brought to my attention was about part time programmes meant for school teachers, running only during school holidays. Perhaps this view of this particular teacher-student captures the situation vividly:

"The whole system is outrageous. How can you talk about quality when we only do a maximum of 3 weeks at a time- three times a year, during school holidays. We are largely on our own the rest of the time, even without any support or books. Just go to the library to and see for yourself if there are any books there! It's good the lecturers don't even have time to mark our papers. I know this for sure because last time I was so busy with work and I didn't have books. All I could do is buy a friend's report and tweak it a little bit. I escaped, but I'm not telling anyone to try it." (Personal Interview, July 2010)

More indicting was the state of post graduate programmes:

"We are really fed up. We have taken close to four years for a programme that was meant to take just two years. Nothing is right here". (Personal Interview, July 2010)

4.2 Delphi Results

Table 3. Demographic information

\begin{tabular}{llll}
\hline & & Percentage \\
\hline Targeted & & 36 & 100 \\
Responded & Private universities & 6 & 83.3 \\
& Public universities & 24 & \\
\multirow{2}{*}{ Did not respond } & Total & 30 & \\
& & 6 & 17.6 \\
\hline
\end{tabular}

Table 3 above represents the demographic details of the respondents recruited for the Delphi study.

Sample responses to round one open ended question:

'Pathetic. The numbers are just unmanageable effectively'

'More and more students in the lecture room, but not enough staff or facilities'

'Can't speak for others, but for us, we have confidence in our products. I believe they are the best that you can find in the market. Quality is all we care about. The market can bear testimony to this. We feel proud of our graduates. We admit just a few but we build their potential to the uttermost'

'Quality is a misnomer in Kenyan HE. It just does not exist. God forbid, we have just turned out into faulty production lines, but we bite more than we can chew. I wish the government could do something to change this'

'You will agree with me that given a choice between quantity and quality, any reasonable person will go for 
quality. Unfortunately for our institutions it is volumes that matter'

(Delphi Survey, July 2010)

From the first round it was obvious that most of the panel members were concerned about the quantity-quality mismatch in HE in Kenya. The second round was to identify the aspects of quality that they found critical in so far as HE institutions in Kenya were concerned.

The following were the major themes that were pointed out for them for the second round:

- Breadth of teaching

- Learning and assessment activities

- Students achievement

- The curriculum

- Learning resources

- Student support and guidance

- Academic management at subject/dept level

Therefore this round was to help gauge the extent to which the panel considered these aspects in practice at the Kenyan universities. So in this round they were expected to rate each aspect on a three point scale-excellent, satisfactory and unsatisfactory. These are awarded scales of:

- Excellent: 1.00

- Satisfactory: 0.50

- Unsatisfactory: 0.00

The results of the second round were analysed and presented to the panel for their concurrence, in the final round.

The three rounds of the study had response rates of approximately 83.3 percent, 100 percent, and 100 percent respectively. Telephone and email reminders proved useful in ensuring the 100 percent response rates in the second and final rounds.

\subsubsection{Reliability Statistics}

Table 4. Cronbach's Alpha

\begin{tabular}{c|c}
\hline Cronbach's Alpha & N of Items \\
\hline .891 & 7 \\
\hline
\end{tabular}

To establish the reliability of the instrument, Cronbach's alpha test was carried out, which revealed an acceptable measure as presented above. 


\subsubsection{Factor Scores}

Table 5. Factor Scores

\begin{tabular}{|c|c|c|c|c|c|c|}
\hline & Factor & & Frequency & Percent & Valid Percent & Cumulative Percent \\
\hline \multirow[t]{4}{*}{ Breadth of teaching } & \multirow[t]{4}{*}{ Valid } & Unsatisfactory & 10 & 33.3 & 33.3 & 33.3 \\
\hline & & Satisfactory & 18 & 60.0 & 60.0 & 93.3 \\
\hline & & Excellent & 2 & 6.7 & 6.7 & 100.0 \\
\hline & & Total & 30 & 100.0 & 100.0 & \\
\hline \multirow{4}{*}{$\begin{array}{l}\text { Learning } \\
\text { activities }\end{array}$} & \multirow[t]{4}{*}{ Valid } & Unsatisfactory & 9 & 30.0 & 30.0 & 30.0 \\
\hline & & Satisfactory & 20 & 66.7 & 66.7 & 96.7 \\
\hline & & Excellent & 1 & 3.3 & 3.3 & 100.0 \\
\hline & & Total & 30 & 100.0 & 100.0 & \\
\hline \multirow[t]{4}{*}{ Students' achievement } & \multirow[t]{4}{*}{ Valid } & Unsatisfactory & 9 & 30.0 & 30.0 & 30.0 \\
\hline & & Satisfactory & 19 & 63.3 & 63.3 & 93.3 \\
\hline & & Excellent & 2 & 6.7 & 6.7 & 100.0 \\
\hline & & Total & 30 & 100.0 & 100.0 & \\
\hline \multirow[t]{4}{*}{ The curriculum scores } & \multirow[t]{4}{*}{ Valid } & Unsatisfactory & 1 & 3.3 & 3.3 & 3.3 \\
\hline & & Satisfactory & 27 & 90.0 & 90.0 & 93.3 \\
\hline & & Excellent & 2 & 6.7 & 6.7 & 100.0 \\
\hline & & Total & 30 & 100.0 & 100.0 & \\
\hline \multirow[t]{4}{*}{ Learning resources } & \multirow[t]{4}{*}{ Valid } & Unsatisfactory & 20 & 66.7 & 66.7 & 66.7 \\
\hline & & Satisfactory & 9 & 30.0 & 30.0 & 96.7 \\
\hline & & Excellent & 1 & 3.3 & 3.3 & 100.0 \\
\hline & & Total & 30 & 100.0 & 100.0 & \\
\hline \multirow[t]{4}{*}{ Student support \& guidance } & \multirow[t]{4}{*}{ Valid } & Unsatisfactory & 9 & 30.0 & 30.0 & 30.0 \\
\hline & & Satisfactory & 19 & 63.3 & 63.3 & 93.3 \\
\hline & & Excellent & 2 & 6.7 & 6.7 & 100.0 \\
\hline & & Total & 30 & 100.0 & 100.0 & \\
\hline \multirow{4}{*}{$\begin{array}{l}\text { Academic management at } \\
\text { subject/dept. level }\end{array}$} & \multirow{4}{*}{ Valid } & Unsatisfactory & 11 & 36.7 & 36.7 & 36.7 \\
\hline & & Satisfactory & 17 & 56.7 & 56.7 & 93.3 \\
\hline & & Excellent & 2 & 6.7 & 6.7 & 100.0 \\
\hline & & Total & 30 & 100.0 & 100.0 & \\
\hline
\end{tabular}

The responses were analysed by calculating the means, standard deviation and variance for each factor as presented in Table 5 above.

Table 6. Comparative statistics

\begin{tabular}{llllllll}
\hline & $\begin{array}{l}\text { Breadth of } \\
\text { teaching }\end{array}$ & $\begin{array}{l}\text { Learning } \\
\text { assessment } \\
\text { activities }\end{array}$ & $\begin{array}{l}\text { Students' } \\
\text { achievement }\end{array}$ & $\begin{array}{l}\text { The } \\
\text { curriculum }\end{array}$ & $\begin{array}{l}\text { Learning } \\
\text { resources }\end{array}$ & $\begin{array}{l}\text { Student support } \\
\text { \& guidance }\end{array}$ & $\begin{array}{l}\text { Academic } \\
\text { management at } \\
\text { subject/dept. } \\
\text { level }\end{array}$ \\
\hline NValid & 30 & 30 & 30 & 30 & 30 & 30 & 30 \\
Missing & 0 & 0 & 0 & 0 & 0 & 0 & 0 \\
Mean & .3667 & .3667 & .3833 & .5167 & .1833 & .3833 & .3500 \\
Std. Deviation & .29165 & .26042 & .28416 & .15992 & .27803 & .28416 & .29798 \\
Variance & .085 & .068 & .081 & .026 & .077 & .081 & .089 \\
\hline
\end{tabular}

Table 6 above presents the comparative statistics for all the factors.

Table 7. Kendall's Coefficient of Concordance

\begin{tabular}{ll}
\hline $\mathrm{N}$ & 30 \\
\hline Kendall's W(a) & .228 \\
Chi-Square & 40.971 \\
$\mathrm{Df}$ & 6 \\
Asymp. Sig. & .000 \\
\hline
\end{tabular}


Finally, to establish the extent of agreement by the respondents on each of the seven critical factors, Kendall's W test was carried out. The result is as shown in Table 6 above.

This indicates that the respondents are fairly agreeable on the critical elements of quality in the HE in Kenya and if their responses here are anything to go by, this reflects a very poorly on all the aspects of HE quality: Breadth of teaching, learning and assessment activities, students' achievement, the curriculum, learning resources, student support and guidance, and academic management at subject/ department level.

\section{Conclusion and Recommendations}

The results derived from this study speak volumes as to the state of affairs in the HE institutions in Kenya and reinforces the conclusions arrived at by among others Ouma-Wangege (2007). The rapid increase in student intake without corresponding expansion of facilities and recruitment of staff, calls to question the whole policy of widening access and massification. The Government of Kenya, through the Ministry of Higher Education and Commission for Higher Education have always portrayed false confidence in the sector, perhaps with the intention of not creating an alarm. The universities themselves have not wished to be portrayed in bad light and have tended to also play ball in downplaying the issue. Fortunately, Mr. William Ruto, the former Minister for Higher Education seemed to have taken notice and in his address on September 7, 2010, he vigorously decried the quality standards in the Kenyan HE system (Mathenge, 2010).

There are several aspects that require reform in the HE in Kenya, but particularly with respect to quality assurance, some of the measures that may need to be taken urgently include:

1. Expansion of infrastructure and facilities- it is common knowledge that the infrastructure and facilities in the HEIs in Kenya are completely run down. The increasing numbers of students has just put too much strain on these facilities. Therefore, there is an urgent need to expand and improve facilities.

2. Recruitment of adequate qualified staff. Universities in Kenya froze employment of new lecturers long ago due to financial constraints. In order to ensure quality and productivity, it is imperative that additional academic staff be hired. This would ensure acceptable student-staff ratio, commensurate with the increasing student numbers.

3. Review and restructuring of programmes offered and thereafter, regular reviews to make sure that they are in tandem with Vision 2030; the overall development agenda envisaged by the Government of Kenya. The Vision 2030 has identified fields to do with science, technology, engineering, and medicine as the drivers for growth but few universities have this orientation. So universities need to change course.

4. Establishing and strengthening of the quality assurance units within the universities and making sure that they engage effectively with the academics. Having a dormant quality assurance unit, tucked away somewhere like is the case in many universities in kenya, makes no sense. These units need to actively engage with faculty

5. Establishing a robust external quality assurance system and an overall body to ensure greater accountability. Global trends indicate that most countries, for example, UK, Europe, Autralia, have all adopted external HE quality assurance bodies. These examples are worth emulating. So for a more accountable and quality assured HE system, Kenya needs to have some mechanism for external quality assurance.

6. Enhancing the role of Commission for Higher Education in coordination and regulation in the HE sector for both public and private institutions. Indeed as found out in this study, and previous studies, the public universities are untouchable and Commission for Higher Education, even though it has the mandate cannot regulate their activities. I reckon that a bill to effect this has been drafted and is awaiting debate in parliament. If the bill is eventually passed into law then it will be a major step forward that will give way to an Act of Parliament to provide for the development of university education, the establishment, accreditation and governance of universities, the establishment of the Commission for University Education, University Funding Board and the Kenya University Admissions Board; the repeal of certain laws, and for connected purposes also bring some sanity to the HE sector.

Without doing these, the numbers churned out of the universities will not be any productive and the country's future would be in great jeopardy.

\section{References}

Alexander, F. K. (2000). The Changing Face of Accountability: Monitoring and Assessing Institutional Performances in Higher Education. The Journal of Higher Education, 71, 411-431. http://dx.doi.org/10.2307/2649146

Barnett, R. (1992). Improving Higher Education: Total quality care. Buckingham: SRHE/Open University Press. 
Barnett, R. (1994). The idea of quality: Voicing the educational. In Doherty, G. D. (Eds.), Developing Quality Systems in Higher Education. London: Routledge.

Brooks, K. W. (1979). Delphi technique: Expanding applications. North Central Association Quarterly, 54, 377-385.

Burrows, A., \& Harvey, L. (1992). Defining quality in higher education: The stakeholder approach. Paper presented at the AETT Conference on Quality in Education, University of York, 6-8 April.

Cheng, Y. C., \& Tam, W. M. (1997). Multi-models of quality in education. Quality Assurance in Education, 5(1), 22-31. http://dx.doi.org/10.1108/09684889710156558

Committee of Vice-Chancellors and Principals of the Universities of the United Kingdom and University Grants Committee (CVCP/UGC). (1986). Performance Indicators in Universities: A first statement by joint CVCP/UGC Working Group. London; CVCP.

Court, D., \& Ghai, D. (1974). Education, society and development: New perspectives from Kenya. Nairobi: Oxford University Press.

Cowen, R. (1996). The evaluation of higher education systems. London, England: Kogan Page.

Crosby, P. B. (1979). Quality Is Free: The Art of Making Quality Certain. New York, NY: New American Library.

Custer, R. L., Scarcella, J. A., \& Stewart, B. R. (1999). The modified Delphi technique: A rotational modification. Journal of Vocational and Technical Education, 15(2), 1-10. Retrieved July10, 2010, from http://scholar.lib.vt.edu/ejournals/JVTE/v15n2/custer.html

Cyphert, F. R., \& Gant, W. L. (1971). The Delphi technique: A case study. Phi Delta Kappan, 52, 272-273.

Dalkey, N. C., \& Helmer, O. (1963). An experimental application of the Delphi method to the use of experts. Management Science, 9, 458-467. http://dx.doi.org/10.1287/mnsc.9.3.458

David, P. (1997, October 2). Inside the knowledge factory. The Economist. Retrieved July 10, 2010, from http://www.economist.com/node/600142

Feigenbaum, A. V. (1951). Quality Control: Principles, Practice, and Administration. New York, NY: McGraw-Hill.

Gilmore, H. L. (1974). Product conformance cost. Quality Progress, 7(5), 16-19.

Harvey, L., \& Green, D. (1993). Defining quality. Assessment \& Evaluation in Higher Education, 18(1), 9-34. http://dx.doi.org/10.1080/0260293930180102

Johnes, J., \& Taylor, J. (1990). Performance Indicators in Higher Education. Buckingham: SRHE \& Open University Press.

Jowi, J. (2003). Governing Higher Education in the stakeholder society: Rethinking the role of the state in Kenya's higher education. Paper presented at the CHEPS Summer School, June 29 - July 42003 , University of Maribor, Slovenia.

Juran, J. M., \& Gryna, F. M. Jr (Eds.). (1988). Juran's Quality Control Handbook (4th ed.). New York, NY: McGraw-Hill.

Mathenge, O. (2010, September 6). Govt alert over Kenya university standards. Daily Nation, p. 1-2.

Mulunda, L,. \& Ondari, J. (2010, June 9). Uhuru's Budget the biggest in history. Daily Nation. Retrieved July10, 2010, from http://www.nation.co.ke/News/Uhuru\%20Budget\%20the\%20\%20biggest\%20in\%20history//1056/935672/-/jx0ehr/-/index.html

Ngome, C. (2003). Kenya. In D. Teferra \& P. G. Altbach (Eds.), African Higher Education: An International Reference Handbook (pp. 359-371). Bloomington: Indiana University Press.

Parasuraman, A., Zeithaml, V. A., \& Berry, L. L. (1985). A conceptual model of service quality and its implications for future research. Journal of Marketing, 49(4), 41-50. http://dx.doi.org/10.2307/1251430

Patrick, W. J., \& Stanley, E. C. (1998). Teaching and research quality indicators and the shaping of higher education. Research in Higher Education, 39, 19-41. http://dx.doi.org/10.1023/A:1018700327881

Peters, T. J., \& Waterman, R. H. (1982). In Search of Excellence. New York, NY: Harper \& Row.

Saarinen, T. (2010). What I Talk About When I Talk About Quality. Quality in Higher Education, 16(1), 55-57. 
http://dx.doi.org/10.1080/13538321003679507

Schuller, T. (Eds.). (1991). The Future of Higher Education. Milton Keynes: SRHE \& Open University Press.

Scott, P. (1995). The Meanings of Mass Higher Education. Buckingham: SRHE \& Open University Press.

Sifuna, D. (1998). The governance of Kenyan public universities. Research in Post-secondary Education, 3(2).

Tam, M. (2001). Measuring Quality and Performance in Higher Education. Quality in Higher Education, 7(1), 47-54. http://dx.doi.org/10.1080/13538320120045076

Wangenge-Ouma, G. (2007). Higher education marketisation and its discontents: The case of quality in Kenya. Higher Education, 56, 457-471. http://dx.doi.org/10.1007/s10734-007-9104-2

World Bank. (2004). Facilitating Investment in the Global Education Market. Washington, DC: World Bank. 